\title{
Zakres obowiązku przedstawienia przez wnioskodawcę projektu ustawy założeń podstawowych aktów wykonawczych ${ }^{1}$
}

The scope of a sponsor's of the bill obligation to present outline drafts of principal executive orders (WAKiU-316/18): An obligation, provided for in the Standing Orders of the Sejm, of a sponsor's of the bill to present to present outline drafts of principal executive orders is one of the core procedural regulations shaping the content of an explanatory statement of a bill. If the sponsor does not plan to issue any executive orders on the bases on the bill, it has to be indicated in the explanatory statement of the bill, as an information about legal consequences of the bill. In case when entry into force of the statute will result in the necessity of modifying executive orders being in force, it should be notified while presenting the above-mentioned legal consequences.

Keywords: legislative procedure, bill, Standing Orders of the Sejm

Słowa kluczowe: postępowanie ustawodawcze, projekt ustawy, regulamin Sejmu

Doktor nauk prawnych, Wydział Prawa i Administracji Uniwersytetu Kardynała Stefana Wyszyńskiego w Warszawie, ekspert ds. legislacji BAS; piotr.chybalski@sejm.gov.pl.

\section{Przedmiot opinii}

Przedmiotem niniejszej opinii jest odpowiedź na dwa pytania odnoszące się do zakresu obowiązku przedstawienia przez wnioskodawcę projektu ustawy założeń podstawowych aktów wykonawczych (art. 34 ust. 2 pkt 6 regulaminu Sejmu). Opinia powstała w związku z pismem wicemarszałek Sejmu, w którym m.in. zwrócono się do przedstawicielki wnioskodawców poselskiego projektu ustawy o zmianie ustawy o mniejszościach narodowych i etnicznych oraz o języku regionalnym, oraz niektórych innych ustaw ${ }^{2}$ o uzupełnienie uzasadnienia tego projektu zgodnie z przywołanym wyżej wymogiem regulaminowym.

Opinia sporządzona 9 marca 2018 r. na zlecenie Klubu Poselskiego Nowoczesna; BASWAKiU 316/18.

2 Projekt został wniesiony 11 stycznia 2018 r., zob. http://orka.sejm.gov.pl/Druki8ka. nsf/Projekty/8-020-816-2018/\$file/8-020-816-2018.pdf [dostęp 8 marca 2018 r.]. 


\section{Uwagi ogólne}

Przewidziany w art. 34 ust. 2 pkt 6 regulaminu Sejmu wymóg przedstawienia przez wnioskodawcę projektu ustawy założeń podstawowych aktów wykonawczych należy do podstawowych rozwiązań regulaminowych kształtujących treść uzasadnienia projektu ustawy. Przepis ten obowiązuje bez zmian od wejścia w życie regulaminu Sejmu33. Co więcej, tworząc regulamin Sejmu w 1992 r., analizowany wymóg przeniesiono in extenso z art. 33 ust. 2 pkt 5 regulaminu Sejmu PRL z 17 lipca 1986 r. (tekst pierwotny, M.P. nr 21, poz. 151). Oznacza to, iż de facto obowiązuje on już ponad 30 lat, mimo kilkakrotnych zasadniczych przeobrażeń ustrojowych, odnoszących się również do kwestii wydawania aktów wykonawczych do ustaw. Taki stan rzeczy nakazuje podać w wątpliwość celowość dalszego utrzymania w regulaminie art. 34 ust. 2 pkt 6 regulaminu Sejmu w obecnym kształcie, który to wątek jest rozwinięty w dalszej części tekstu.

Odnosząc się do wykładni analizowanego przepisu, należy uznać, że wymóg uwzględnienia w uzasadnieniu projektu ustawy założeń podstawowych aktów wykonawczych stanowi wycinek ogólnego obowiązku przedstawienia w uzasadnieniu wywieranych przez projekt skutków prawnych (art. 34 ust. 2 pkt 4 regulaminu Sejmu), które to pojęcie należałoby interpretować szeroko, a zarazem ogólnie - jako przewidywany wpływ projektowanych przepisów na system prawa. Nie ulega wątpliwości, że szczegółowy wymóg przedstawienia przez wnioskodawcę projektu ustawy założeń podstawowych aktów wykonawczych okazał się dla Sejmu na tyle istotny, że izba zdecydowała się wyróżnić go w osobnym przepisie regulaminowym. Obowiązek ten ma charakter „kontrolny”, ponieważ jak zauważył M. Kudej - znajomość zamiarów legislacyjnych w zakresie aktów wykonawczych do projektowanej ustawy umożliwia Sejmowi pełniejszą kontrolę nad treścią tworzonego prawa, gdyż: można uniknać nadmiernej dowolności w kształtowaniu treści aktów wykonawczych przez upoważnione organy ${ }^{4}$. Jakkolwiek uwaga ta odnosiła się do wymogu dołączenia przez Radę Ministrów do projektów rządowych projektów podstawowych aktów wykonawczych (art. 34 ust. 4 regulaminu Sejmu, zob. dalsze rozważania), to wydaje się, że myśl w niej wyrażona jest adekwatna do analizowanego obowiązku zawartego w art. 34 ust. 2 pkt 6 regulaminu Sejmu ${ }^{5}$. Zarazem jednak trzeba podkreślić archaiczność tego rozwiązania regulaminowego. W świetle aktualnego standardu konstytucyjnego (art. 92 ust. 1 Konstytucji) zakres swobody organu upoważnionego ustawowo do wydania rozporządzenia jest w obszarze kształtowania treści rozporządzenia dalece ograniczony, gdyż konieczne jest uwzględnienie zawartych w przepisie

3 Pierwotnie oznaczony był jako art. 31 ust. 2 pkt 6.

4 M. Kudej, Instytucje polskiego prawa parlamentarnego z zakresu legislacji, Katowice 1995, s. 22.

5 Zob. też A. Szmyt, Nowe elementy konstytucyjne i regulaminowe postępowania ustawodawczego, „Przegląd Sejmowy” 1998, nr 3, s. 34. 
upoważniającym wytycznych dotyczących treści aktu. Właśnie treść wytycznych, a nie treść założeń aktu wykonawczego, nawet stosunkowo szczegółowych, ukierunkowuje czynności prawotwórcze organu wydającego rozporządzenie, co oznacza, że w sferze nieobjętej zakresem wytycznych a zarazem objętej zakresem założeń uwzględnionych w uzasadnieniu projektu ustawy organ wydający rozporządzenie cieszy się znaczną swobodą regulacyjną. Przykładowo grupa posłów wnosząca projekt ustawy nie może - poprzez szczegółowe opisanie w uzasadnieniu założeń wydawanych na podstawie projektu podstawowych aktów wykonawczych - narzucić organowi obowiązanemu do wydania rozporządzenia, np. Krajowej Radzie Radiofonii i Telewizji, sposobu czy kierunku regulacji przepisów zawartych w tym akcie wykonawczym. Tym samym zasygnalizowany wcześniej „kontrolny” cel wymogu określonego zawartego w art. 34 ust. 2 pkt 6 regulaminu Sejmu wydaje się obecnie co najmniej dyskusyjny.

Należy nadmienić, że analizowany przepis odnosi się formalnie do wszystkich wnioskodawców projektów ustaw, w wyniku czego nabiera on charakteru normy lex generalis względem dwóch rozwiązań regulaminowych adresowanych do Rady Ministrów, tj. obowiązku dołączenia przez ten organ do projektów rządowych projektów podstawowych aktów wykonawczych (art. 34 ust. 4 regulaminu Sejmu) oraz do rządowych projektów ustaw wykonujących prawo Unii Europejskiej - projektów aktów wykonawczych, których obowiązek wydania przewiduje projekt ustawy (art. 34 ust. 4a regulaminu Sejmu). Poza sferą regulowaną przez dwa wskazane przepisy (inicjatywy ustawodawcze Rady Ministrów) art. 34 ust. 2 pkt $6 \mathrm{w}$ pełni reguluje zakres obowiązku wnioskodawcy projektu ustawy w obszarze aktów wykonawczych przewidzianych przez dany projekt.

Zawarte w art. 34 ust. 2 pkt 6 regulaminu Sejmu pojęcie „podstawowych aktów wykonawczych" może wywoływać wątpliwości interpretacyjne z powodu swojej nieostrości. W praktyce sejmowej od wielu lat interpretuje się je jednak jednolicie, w sposób zaproponowany przez A. Gwiżdża, tj. jako akty wykonawcze, których wydanie jest, w świetle danej ustawy, obligatoryjne, innymi słowy, których wydanie zostało nakazane w przepisach ustawowych ${ }^{6}$. Mimo to należy zasygnalizować, że wykładnia ta jest problematyczna $z$ uwagi na to, że w przywołanym wyżej art. 34 ust. 4a regulaminu Sejmu występuje pojęcie „projektów aktów wykonawczych, których obowiązek wydania przewiduje projekt ustawy". Tym samym de facto oba, odmienne terminy regulaminowe interpretuje się w taki sam sposób, co świadczy o niespójności terminologicznej w obrębie art. 34 regulaminu Sejmu. Korekta takiego stanu rzeczy wymagałaby interwencji legislacyjnej polegającej zapewne na ujednoliceniu terminologii. Jest to jednak problem, który nie wpływa na treść odpowiedzi na problemy szczegółowe, wynikające z pytania zawartego we wstępie opinii.

6 A. Gwiżdż, Ustawodawstwo i kompetencje prawotwórcze rządu [w:] „Mała Konstytucja" w procesie przemian ustrojowych w Polsce, red. M. Kruk, Warszawa 1993, s. 111. 


\section{Uwagi szczegółowe}

1. Czy wymagane jest przedstawienie założeń projektów podstawowych aktów wykonawczych, których obowiązek wydania wynika z treści poselskiego projektu ustawy, jeśli projekt ustawy nie przewiduje wydania żadnych aktów wykonawczych, a jeśli tak, to jak te podstawowe założenia powinny być ujęte w uzasadnieniu?

W moim przekonaniu, w przypadku gdy projekt ustawy nie przewiduje wydania jakichkolwiek aktów wykonawczych, należy - jak się wydaje z oczywistych względów - uznać, że nie aktualizuje się wymóg przewidziany w art. 34 ust. 2 pkt 6 regulaminu Sejmu. Zastosowanie znajdzie tu zasada wyrażona w paremii prawniczej impossibilium nulla obligatio est (w wolnym tłumaczeniu „nie ma zobowiązania, gdy świadczenie jest niemożliwe”). Należałoby natomiast - w treści informacji o skutkach prawnych projektu (wspomniany art. 34 ust. 2 pkt 4 regulaminu Sejmu) - wskazać w uzasadnieniu, że nie zakłada się wydania jakichkolwiek nowych aktów wykonawczych na podstawie projektowanych przepisów.

Na marginesie warto dodać, że analiza poselskiego projektu ustawy o zmianie ustawy o mniejszościach narodowych i etnicznych oraz o języku regionalnym, oraz niektórych innych ustaw wskazuje, że nie obejmuje on przepisów nakazujących wydanie nowych aktów wykonawczych. Jak zostanie jednak wskazane niżej, zakłada się modyfikację jednego przepisu ustawowego, który zawiera delegację do wydania obowiązującego obecnie rozporządzenia.

2. Czy wymagane jest przedstawienie założeń projektów podstawowych aktów wykonawczych, jeśli poselski projekt ustawy przewiduje jedynie zmianę treści obowiązującego aktu wykonawczego, a jeśli tak, to jak te podstawowe założenia powinny być ujęte w uzasadnieniu?

Uważam, że w przypadku opisanym w pytaniu również nie aktualizuje się wymóg określony w art. 34 ust. 2 pkt 6 regulaminu Sejmu, gdyż przepis ten odnosi się wyłącznie do sytuacji, gdy konsekwencją projektowanych przepisów ustawowych jest konieczność wydania nowych aktów wykonawczych. Z kolei sytuacja, w której skutkiem wejścia w życie tworzonej ustawy będzie konieczność modyfikacji obowiązujących aktów wykonawczych, powinna zostać zasygnalizowana w uzasadnieniu projektu w treści wspomnianej prezentacji skutków prawnych (art. 34 ust. 2 pkt 4 regulaminu Sejmu).

Odnosząc powyższe uwagi do poselskiego projektu ustawy o zmianie ustawy o mniejszościach narodowych i etnicznych oraz o języku regionalnym, należy odnotować, że w art. 3 pkt 2 przewiduje zmianę art. 15 ust. 4 pkt 3 ustawy z 29 grudnia 1992 r. o radiofonii i telewizji (Dz.U. 2017, poz. 1414, ze zm.). Prima facie, oznacza to modyfikację zakresu delegacji ustawowej do wydania przewidzianego w tym przepisie rozporządzenia Krajowej Rady Radiofonii i Telewizji, a tym samym konieczność znowelizowania wydanego na podstawie tego przepisu rozporządzenia Krajowej Rady Radiofonii i Telewizji z 18 maja 2016 r. w sprawie niższego udziału w programie telewizyjnym audycji wytwo- 
rzonych pierwotnie w języku polskim i audycji europejskich oraz w programie radiowym utworów słowno-muzycznych wykonywanych w języku polskim (Dz.U. poz. 779). Bliższa analiza problemu wskazuje jednak, że nawet w wyniku zmienionej delegacji ustawowej możliwe byłoby utrzymanie przywołanego rozporządzenia w aktualnej wersji. Problem wynika $z$ - jak się wydaje - nietrafnego założenia wnioskodawców projektu, że wprowadzenie języka śląskiego jako drugiego (obok kaszubskiego) języka regionalnego (co stanowi clue analizowanego projektu) sprawia, iż legislacyjnie niezbędna jest zamiana występującego w obowiązujących przepisach prawa pojęcia „język regionalny” na "na języki regionalne”. Tymczasem pojęcie „języka regionalnego” należy rozumieć nie jako synonim języka kaszubskiego jako jedynego w obecnym stanie prawnym języka regionalnego, lecz kategorialnie - jako klasę (zbiór) obejmującą wszystkie języki uznane prawem za języki regionalne ${ }^{7}$. W konsekwencji dodanie nowego języka regionalnego wydaje się nie wymagać tak daleko idących zmian prawnych, jak proponują wnioskodawcy projektu. W szczególności nie wydaje się konieczne modyfikowanie wspomnianego art. 15 ust. 4 pkt 3 ustawy o radiofonii i telewizji, a także wydanego na podstawie tego przepisu rozporządzenia Krajowej Rady Radiofonii i Telewizji z 18 maja 2016 r.

$\mathrm{W}$ razie niepodzielenia powyższych uwag, a tym samym utrzymanie w projekcie przepisu zakładającego modyfikację art. 15 ust. 4 pkt 3 ustawy o radiofonii i telewizji, fakt formalnej zmiany delegacji do wydania ww. rozporządzenia należy odnotować w uzasadnieniu projektu jako konsekwencję wymogu przedstawienia skutków prawnych projektu (art. 34 ust. 2 pkt 4 regulaminu Sejmu).

\section{Podsumowanie}

W podsumowaniu należy przedstawić efekty rozważań zaprezentowanych w niniejszej opinii.

- Jeśli projekt ustawy nie przewiduje wydania jakichkolwiek aktów wykonawczych, to w myśl zasady impossibilium nulla obligatio est nie aktualizuje się przewidziany w art. 34 ust. 2 pkt 6 regulaminu Sejmu wymóg przedstawienia w uzasadnieniu projektu założeń podstawowych aktów wykonawczych. Należałoby natomiast - w treści informacji o skutkach prawnych projektu (wspomniany art. 34 ust. 2 pkt 4 regulaminu Sejmu) - wskazać w uzasadnieniu, że nie zakłada się wydania jakichkolwiek nowych aktów wykonawczych na podstawie projektowanych przepisów.

7 Co więcej, zakładane w projekcie wprowadzenie pojęcia „społeczności posługujących się językami regionalnymi” może być interpretowane jako takie społeczności, które posługują się łącznie co najmniej dwoma językami regionalnymi - co wydaje się oczywiście sprzeczne z intencjami wnioskodawców projektu. 
- W sytuacji, gdy skutkiem wejścia w życie tworzonej ustawy będzie konieczność modyfikacji obowiązujących aktów wykonawczych (np. w wyniku zmiany zakresu ustawowej delegacji do wydania aktu wykonawczego), należy fakt ten zasygnalizować $\mathrm{w}$ uzasadnieniu projektu we wspomnianej prezentacji skutków prawnych (art. 34 ust. 2 pkt 4 regulaminu Sejmu).

- Wydaje się, że wnioskodawcy poselskiego projektu ustawy o zmianie ustawy o mniejszościach narodowych i etnicznych oraz o języku regionalnym proponują zbyt szerokie zmiany obowiązujących przepisów. Mówiąc nieco inaczej, realizacja założonego przez wnioskodawców celu, tj. uznania języka śląskiego za język regionalny, nie wymaga wprowadzenia tak znacznych zmian przepisów ustawowych, jak przewidziano w projekcie.

\section{Bibliografia}

Gwiżdż A., Ustawodawstwo i kompetencje prawotwórcze rządu [w:] „Mała Konstytucja” $w$ procesie przemian ustrojowych w Polsce, red. M. Kruk, Warszawa 1993.

Kudej M., Instytucje polskiego prawa parlamentarnego z zakresu legislacji, Katowice 1995. Szmyt A., Nowe elementy konstytucyjne i regulaminowe postępowania ustawodawczego, „Przegląd Sejmowy” 1998, nr 3. 